\title{
Elder Abuse
}

\author{
Rita Elaine Stuckey* \\ Mills College, USA \\ Submission: June 11, 2017; Published: June 15, 2017 \\ *Corresponding author: Elaine Stuckey, Mills College, USA, Email: rita.stuckey@yahoo.com
}

\section{Opinion}

I have served as a Registered Nurse for the past 33 years and totally appreciated my nursing experiences in acute, long-term acute, psychiatric, skilled nursing, home health, private duty, insurance, surgical and public health care for the adult, pediatric and elderly populations.

Most of my career has embraced Administrative Nursing contracted positions in the San Francisco Bay Area. I had been nursing for approximately 14 years when I received a telephone call to serve as the Interim Director of Nursing for a 99 bed skilled nursing facility that had no director and agreed to a mock survey with The Department of Health and Human Services.

I was only four days on the job when the charge nurse asked to speak with me and pulled me into a utility closet with brooms, mops, detergents and supplies holding my hand and crying profusely. The charge nurse said "Rita, I know you have only been here four days but you need to know that the nurses are physically and sexually abusing the seniors residing in the facility and everyone knows about it". I said" everyone like whom".She replied directors, supervisors, managers and the owner of the facility all know that abuse against the residents was pervasive.

My heart was broken and I cried for a long time. My oldest son said, "Mom, you keep talking about elder abuse but what are you going to do about it?" With all my nursing love for others, I replied "I do not know but I am going to make a significant change." That is when I decided to go back to school earning a Master's degree in Public Administration, Master's degree in Education and Doctorate in Educational Leadership. I am redhot mad that our system has not and does not adequately protect our seniors from abuse at the hand of paid caregivers in the nursing home setting.

In the United States, the 2010 Census recorded the greatest number and proportion of people age 65 and older in all of decennial census history: 40.3 million, or $13 \%$ of the total population. This "Boomer Generation" effect will continue for decades [1]. Between 2012 and 2050, the United States will experience considerable growth in its older population. In 2050, the population aged 65 and over is projected to be 83.7 million, almost double its estimated population of 43.1 million in 2012.3 The number of people in the oldest old age group, which refers to those aged 85 and over, is projected to grow from 5.9 million in 2012 to 8.9 million in 2030. In 2050, this group is projected to reach 18 million [2].

Older women outnumber older men. In 2010, there were 89 men per 100 women among those aged 65 to 69 and 38 men per 100 women among those aged 90 and over. In numerical terms, women outnumbered men by 0.7 million among those aged 65 to 69 , by 1.0 million among those aged 75 to 79 , and by 1.9 million among those aged 85 and over [2].

The Elder Justice Roadmap report uses the following definition of elder abuse: "physical, sexual, or psychological abuse, as well as neglect, abandonments, and financial exploitation of an older person by another person or entity, that occurs in any setting (e.g. home, community, or facility), either in a relationship where there is an expectation of trust and/or when an older person is targeted based on age or disability."This definition was built on from numerous existing definitions, including: those found in laws (such as the federal Elder Justice Act, Older Americans Act, and Violence Against Women Act, various states' laws, and others), and those developed by various entities such as the National Academy of Sciences, the Administration on Aging, the Centers for Disease Control and Prevention, and the New York City Elder Abuse Center [3].

\section{Risk Factors}

A. Women appear to be more likely to be abused than men.

B. Low social support has been found to significantly increase the risk of virtually all forms of mistreatment.

C. Functional impairment and poor physical health are associated with greater risk of abuse among older persons.

D. Lower income or poverty has been found to be associated with elder abuse. Low economic resources have been conceptualized as a contextual or situational stressor contributing to elder abuse. 
E. Experience of previous traumatic events-including interpersonal and domestic violence-has been found to increase the risk for emotional, sexual, and financial mistreatment [4].

\section{Elder Abuse in Nursing Homes and Other Long-Term Care Facilities}

Elder abuse occurs in community settings, such as private homes, as well as institutional settings like nursing homes and other types of long term care facilities. In 2014, the number of nursing home residents was approximately 1.4 million and the number of residents in residential care communities was 835,200 . Concern about elder abuse in nursing homes first came to widespread public attention in the 1970s, when facilities were relatively unregulated and had little oversight.Below is a sampling of research findings relating to abuse in long term care facilities:

A. According to the National Ombudsman Reporting System (NORS) data, within the year 2014, 14,258 (7.6\%) of approximately 188,599 complaints reported to Ombudsman programs involved abuse, gross neglect, or exploitation.

B. A May, 2008 study conducted by the U.S. General Accountability Office revealed that state surveys understate problems in licensed facilities: $70 \%$ of state surveys miss at least one deficiency and $15 \%$ of surveys miss actual harm and immediate jeopardy of a nursing home resident.

C. Abuse of older residents by other residents in longterm care facilities is now recognized as a problem that is more common than physical abuse by staff.

D. However, more research is still needed [5].

\section{Professional Interventions}

\section{Multidisciplinary teams}

Given the complex nature of elder abuse, inter-professional teams, also referred to as multidisciplinary teams consisting of physicians, social workers, law-enforcement personnel, attorneys, and other community participants working together in a coordinated fashion, have been identified as a possibly successful intervention as no single discipline or sector alone has the resources or expertise needed to address the issue [6].

\section{APS guidelines}

Interventions are also developing in reporting and data collection of elder abuse incidents. Adult Protective Services (APS) systems play a critical role in addressing the abuse, neglect, self-neglect, and financial exploitation of adults. Historically, there has been no federal "home" for APS nor a designated federal appropriation for this critically important service. Instead, states and local agencies have developed a wide variety of APS practices, resulting in significant variations between and sometimes within states. In an effort to support Adult Protective Service Agencies and enhance elder abuse response, the Administration on Community Living (ACL) has been developing guidelines intended to assist states in developing efficient and effective APS systems. The NCEA will release more information on this initiative as progress and follow-up research develops [7].

\section{An ombudsman}

An ombudsman or public advocate is an official, usually appointed by the government or by parliament, but with a significant degree of independence, who is charged with representing the interests of the public by investigating and addressing complaints of maladministration or a violation of rights.

I met with the Executive Director of Adult Protective Services and Ombudsman and her response to my concerns were daunting, discouraging and unacceptable. She explained that the department could not possibly manage the influx of abuse reports and the infrastructure of managing abuse reporting has failed our communities. The Care Advocate Program was founded as result of this experience. We serve to advocate on behalf of all seniors and families in every community to protect their right to be free of abuse and neglect at the hands of paid caregivers in a nursing home settings. It is with deepest respect for our seniors and families that we provide all care at no cost.

\section{References}

1. (2014) US Department of Health and Human Services, US Department of Commerce, US Census Bureau.

2. (2014) US Department of Commerce, US Census Bureau.

3. Brandl MT, Breckman R (2014) The Elder Justice Roadmap: A Stakeholder Initiative to Respond to an Emerging Health, Justice, Financial and Social Crisis.

4. (2014) National Center for Health Statistics.

5. Ombudsman: https://en.wikipedia.org/wiki/Ombudsman

6. Friedman B, Santos EJ, Liebel DV, Russ AJ, Conwell Y (2015) Longitudinal prevalence and correlates of elder mistreatment among older adults receiving home visiting nursing. J Elder Abuse Negl 27(1): 34-64.

7. Laumann EO, Leitsch SA, Waite LJ (2008) Elder mistreatment in the United States: prevalence estimates from a nationally representative study. J Gerontol B Psychol Sci Soc Sci 63(4): S248-S254. 
(C) This work is licensed under Creative
Commons Attribution 4.0 License

\section{Your next submission with Juniper Publishers will reach you the below assets}

- Quality Editorial service

- Swift Peer Review

- Reprints availability

- E-prints Service

- Manuscript Podcast for convenient understanding

- Global attainment for your research

- Manuscript accessibility in different formats

( Pdf, E-pub, Full Text, Audio)

- Unceasing customer service

Track the below URL for one-step submission https://juniperpublishers.com/online-submission.php 